DOI 10.18551/rjoas.2021-10.34

\title{
EFFECT OF DIFFERENT PLANT SPECIES ON TILAPIA (OREOCHROMIS SP.) GILL HISTOPATHOLOGY AND WATER QUALITY IN AQUAPONICS SYSTEMS
}

\author{
Pandiangan Immanuel A.H. * \\ Master's Study Program, Department of Aquaculture, Faculty of Fisheries and \\ Marine Science, University of Brawijaya, Indonesia
}

Musa Muhammad

Department of Aquatic Resource Management, Faculty of Fisheries and Marine Science, University of Brawijaya, Indonesia

\author{
Herawati Endang Yuli \\ Department of Aquatic Resource Management, Faculty of Fisheries and Marine Science, \\ University of Brawijaya, Indonesia
}

*E-mail: nuel.pandiangan@gmail.com

\begin{abstract}
Currently, tilapia farming focuses on efficient use of water in reducing nitrogen waste by implementing aquaponics systems. The application of an aquaponic system has advantages not only for producing fish but also plants. This research was carried out for 1 month with different types of plants used, namely water spinach (Ipomoea reptans), pakcoy (Brassica rapa $\mathrm{L}$ ), and control. Each treatment was repeated 3 times. Tilapia fish were used in this study ranging at $8-10 \mathrm{~cm}$ in an aquarium $(60 \times 40 \times 30 \mathrm{~cm})$ with a stocking density of $1 \mathrm{fish} / 2$ liters. Parameters observed included gill histopathology and water quality (ammonia, nitrite and nitrate). The results showed that the damage of fish gill found in the form of hyperflasia, fusion and hemorrhage. The lowest damage to fish gill tissue occurred in treatment $A$ (water spinach) with a score of hyperplasia (0.73), fusion (0.07) and hemorrhage (1.33). The best water quality was obtained in treatment $A$ (water spinach) with values of ammonia $(0.25$ $\mathrm{mg} / \mathrm{l})$, nitrite $(0.174 \mathrm{mg} / \mathrm{l})$, and nitrate $(1.058 \mathrm{mg} / \mathrm{l})$. There is a correlation between the amount of damage to the fish gills and the quality of the water in the rearing media in which the higher the concentration of ammonia and nitrite, the greater the level of damage obtained. Thus, water spinach is the effective plant to utilize nitrogen as an essential nutrient for growth in the aquaculture system.
\end{abstract}

\section{KEY WORDS}

Aquaponic plant, fish culture, nitrogen removal, organic waste materials, recirculating aquaculture system, respiratory organ, sustainable aquaculture.

Tilapia is one of the freshwater fish commodities that are generally cultivated because it has a high-profit value from the economic aspect (Sriyotoet al., 2015). This fish has advantages such as easy cultivation (hatchery), fast growth, and wide tolerance to various environmental conditions (water quality) (Kalibaet al., 2006). Recently, tilapia cultivation activities have focused on the efficient use of fresh water and the waste generated during the cultivation process.

Nitrogen $(\mathrm{N})$ waste in aquaculture systems can be sourced from uneaten feed, fish manure, and dead fish bodies in relatively large quantities (Kawasaki, 2016). Moreover, in closed system aquaculture or recirculation systems, the accumulation of $\mathrm{N}$ in the form of ammonia $\left(\mathrm{NH}_{3}\right)$ in the rearing media is one of the causes of water quality decline that can potentially lead to the failure of tilapia aquaculture activities (Putri et al., 2019).

Ammonia is known as a compound that is toxic to fish. These compounds can penetrate into cell membranes and potentially damage exposed organs (Colt, 2006). Several studies have reported that ammonia can cause damage to various organs. One of the fish 
organs that has a high potential to be affected by this damage is the gills (Farhangiet al., 2014). This condition is related to the function of the gills as respiratory organs in fish that are directly contacted with water. Thus, this organ is directly impacted by the toxicity of xenobiotic compounds and can be used as a bioindicator of water pollution based on morphological changes that occur in the gills (Setyawanet al., 2013; Berliantiet al., 2014; Sweidan et al., 2015; Carvalho et al., 2020).

To control the pollutant waste generated during cultivation activities can be done through an aquaponics system. Aquaponics is a mutually beneficial combination of hydroponic and aquaculture systems to produce plants and fish simultaneously. Aquaponics also has great potential to become a sustainable aquaculture system in the use of nitrogen waste with the production of fish and vegetables simultaneously and efficient in water use (Wongkiewet al., 2017).

Aquaponic plants that have been used in this system have different abilities to absorb $\mathrm{N}$ elements (Deswatiet al., 2018; Andriani et al., 2019; Putri et al., 2019; Rahmadhaniet al., 2020). Water spinach and pakcoy are types of plants that are able to utilize nitrogen in the aquaponics system. Thus, the purpose of this study was to determine the appropriate type of plants on the histopathological conditions of tilapia gills and water quality in aquaponics systems.

\section{MATERIALS AND METHODS OF RESEARCH}

This research was conducted at the Fish Reproduction Laboratory, Faculty of Fisheries and Marine Sciences, Universitas Brawijaya. The aquaponics system was set up using tilapia as test animals. The treatments used were different types of plants using a completely randomized design (CRD) and repeated 3 times. The treatments used consisted of $\mathrm{K}$ (control without plants), A (water spinach), and B (pakcoy).

The size of the tilapia in this study was $8-10 \mathrm{~cm}$ with a stocking density of 1 fish/2 liters of water. Each aquarium $(60 \times 40 \times 30 \mathrm{~cm})$ was filled with water to a height of $25 \mathrm{~cm}$, thus the volume of water was 60 liters. The water spinach and pakcoy plants that were used with a plant age of 7 days after sowing were placed into a hydroponic tray of 10 stems in each treatment and the addition of nitrifying bacteria sourced from commercial probiotics as a starter bacteria (Hartami, et al., 2015; Sukocoet al., 2016). Tilapia was given commercial feed at $5 \%$ of the total weight of the biomass every day. During the maintenance period, the fish were fed with a frequency of 2 times a day. This research was conducted for 1 month.

Tilapia gill samples in each treatment at the end of the rearing were observed histopathologically to determine the level of damage that occurred. Preparation and observation of gill histopathological slides refer to the method of Andayani, et al. (2017). Supporting parameters such as ammonia, nitrite and nitrate were measured weekly using the spectrophotometer method.

The results of all parameters obtained were statistically tested by one-way analysis of variance (ANOVA). If the value of the $F$ test is significantly different or very significantly different, then it is continued with the LSD test (Least Significance Different).

\section{RESULTS AND DISCUSSION}

Figure 1 shows that the ammonia concentration experienced dynamics and the highest increase on day 14 for treatments $A$ and $B$, while the ammonia concentration continued to increase until the end of the study for treatment $\mathrm{K}$. The range of ammonia concentration during the study was $0.07 \mathrm{mg} / \mathrm{l}$ on day 0 until the highest concentration on the 35th day of $1.45 \mathrm{mg} / \mathrm{l}$ for treatment $\mathrm{K}$. The order of the average concentration of ammonia during the study started from the smallest to the largest, starting from treatment $A$ of $0.25 \mathrm{mg} / \mathrm{l}$, treatment $B$ of $0.32 \mathrm{mg} / \mathrm{l}$ and treatment $\mathrm{K}$ of $0.74 \mathrm{mg} / \mathrm{l}$. Based on these results, when compared to other aquaponic studies such as in the study (Suet al., 2020), the smallest ammonia concentration in treatment $A$ was lower than the ammonia concentration of the best treatment in that study, which was $0.42 \mathrm{mg} / \mathrm{l}$. However, when compared to research 
(Gumelaret al., 2017), the smallest ammonia concentration in treatment $A$ was higher than the ammonia concentration of the best treatment in that study, which was $0.13 \mathrm{mg} / \mathrm{l}$. Ammonia reduction that occurs is thought to be caused by the presence of plants that can help the ammonia reduction process. On the other hand, the addition of probiotics as a starter in this system also acts as nitrifying bacteria that utilize nitrogen from ammonia to be converted into nitrite and nitrate. Bacteria belonging to probiotics utilize nitrogen to replicate. The growth rate of probiotic bacteria is highly dependent on the growth phase that occurs (Martin et al., 2003; Mahariawanet al., 2021a). Probiotics can decompose organic matter and reduce ammonia through oxidation mechanisms in aquaculture ponds (Cifuentes-Torres et al., 2021). Probiotic bacteria can absorb nitrogen up to $31.28 \%$ (Mahariawanet al., $2021 b)$.Overall, treatment $A$ gave the best results in reducing ammonia concentration when compared to other treatments.

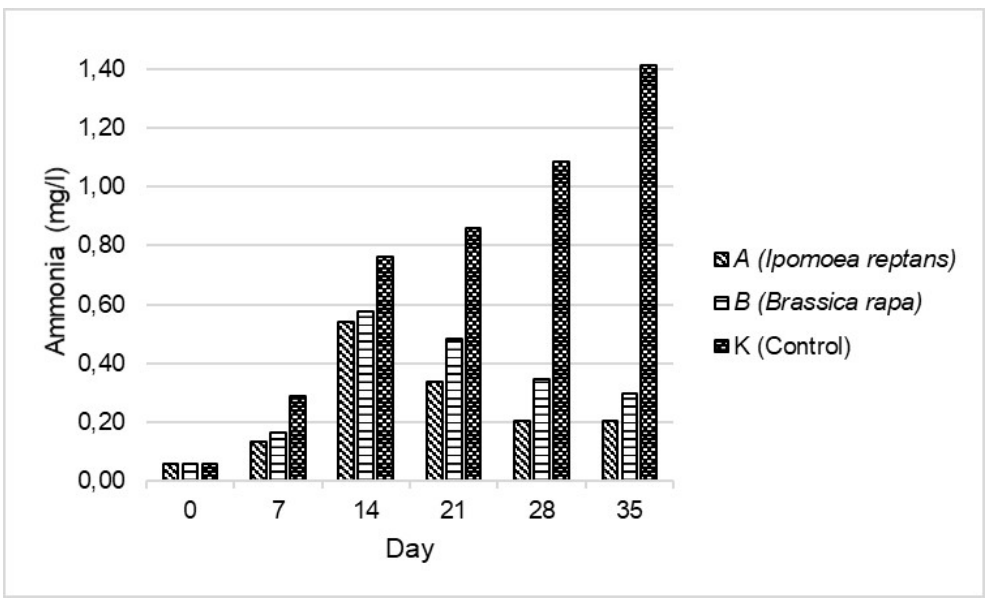

Figure 1 - Ammonia concentration

Figure 2 shows that the nitrite concentration experienced dynamics and the highest increase on day 7 for treatments $A$ and $B$, while the highest nitrite concentration occurred on day 21 for treatment $\mathrm{K}$. The range of nitrite concentration during the study was $0.001 \mathrm{mg} / \mathrm{l}$ on day 0 . until the highest concentration on the $21 \mathrm{st}$ day of $0.559 \mathrm{mg} / \mathrm{l}$ for treatment $\mathrm{K}$. The order of the average concentration of nitrite during the study started from the smallest to the largest, starting from treatment $A$ of $0.174 \mathrm{mg} / \mathrm{l}$, treatment $B$ of $0.213 \mathrm{mg} / \mathrm{l}$ and treatment $\mathrm{K}$ of $0.383 \mathrm{mg} / \mathrm{l}$.

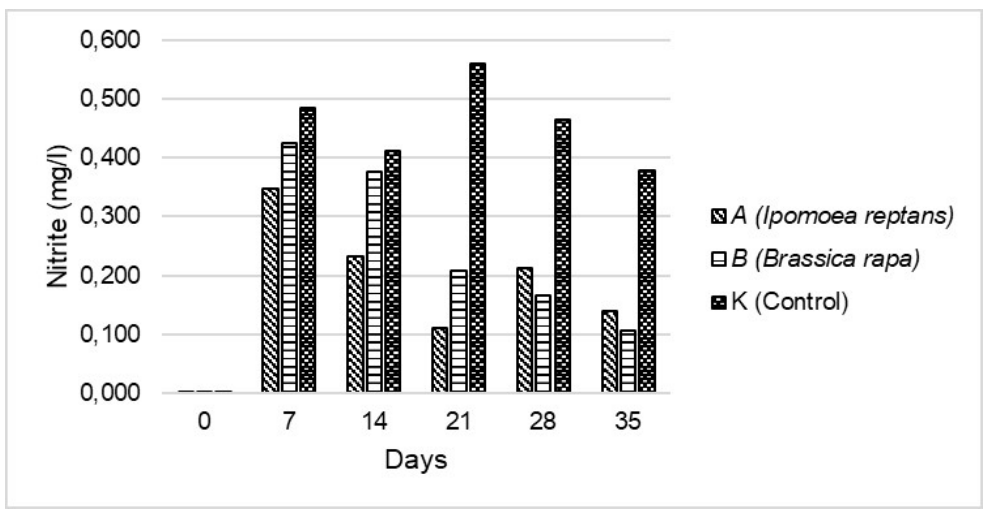

Figure 2 - Nitrite concentration

According to Somerville et al. (2014), a good concentration of nitrite in aquaponic systems ranges from $0.25 \mathrm{mg} / \mathrm{l}-1 \mathrm{mg} / \mathrm{l}$. Based on the results of the weekly nitrite test, all treatments obtained nitrite concentrations below $1 \mathrm{mg} / \mathrm{l}$. This shows that nitrite levels during the study were still within the tolerance limits of fish culture in aquaponics systems. In 
addition, fluctuations in nitrite concentration are thought to occur because nitrite is easily oxidized to nitrate, so that the presence of nitrite in water becomes unstable (Wantasen, 2015). The increase in nitrite concentration during the study could be triggered by the death of the organism, in this study especially due to the death of tilapia (Oreochromis sp.) (Wahyuningsih and Gitarama, 2020) which can be seen clearly in the increase in nitrite concentration in the first week. Overall, treatment A gave the best results in reducing the concentration of nitrite when compared to othertreatments.

Figure 3 shows that the nitrate concentration experienced dynamics and the highest increase was on day 14 for treatments $A$ and $B$, while the highest nitrate concentration for treatment $\mathrm{K}$ occurred on day 35 . The range of nitrate concentration during the study was $0.154 \mathrm{mg} / \mathrm{l}$ on day 0 to the highest concentration on day 35 of $1.931 \mathrm{mg} / \mathrm{l}$ for treatment $\mathrm{K}$. The order of the average concentration of nitrate during the study started from the smallest to the largest, starting from Treatment $A$ was $1.058 \mathrm{mg} / \mathrm{l}$, treatment $B$ was $1.086 \mathrm{mg} / \mathrm{l}$ and treatment $\mathrm{K}$ was $0.726 \mathrm{mg} / \mathrm{l}$. The presence of nitrate content in the treated water media indicates that the nitrification process is running in the system. The ammonia formed has been broken down to the final product in the form of nitrate (Widanarniet al., 2010). The increase in nitrate in the $\mathrm{K}$ treatment was caused by the accumulation of nitrate and no plants were given to absorb nitrate. Nitrate is used by plants as an important nutrient that plays a role in forming proteins that are useful in plant metabolism, especially in the formation of plant chlorophyll (Tuhuteru, 2018), so that the presence of nitrate in the aquaponics system is needed to support the productivity of crop yields. Nitrate is relatively less toxic to fish than ammonia or nitrite, but nitrate can potentially be a problem in the recirculation system. Nitrates can affect osmoregulation and oxygen transport. Nitrate is an oxidizing agent that is able to convert hemoglobin into methemoglobin so that it can affect the hematology of fish, besides that nitrate also has the potential to damage the gill filaments, so that the concentration of nitrate in the cultivation system must be suppressed through the help of plants (Mayunar, 1990; Camargo et al., 2005). Overall, the aquaponic treatment can benefit the nitrate yield in the system.

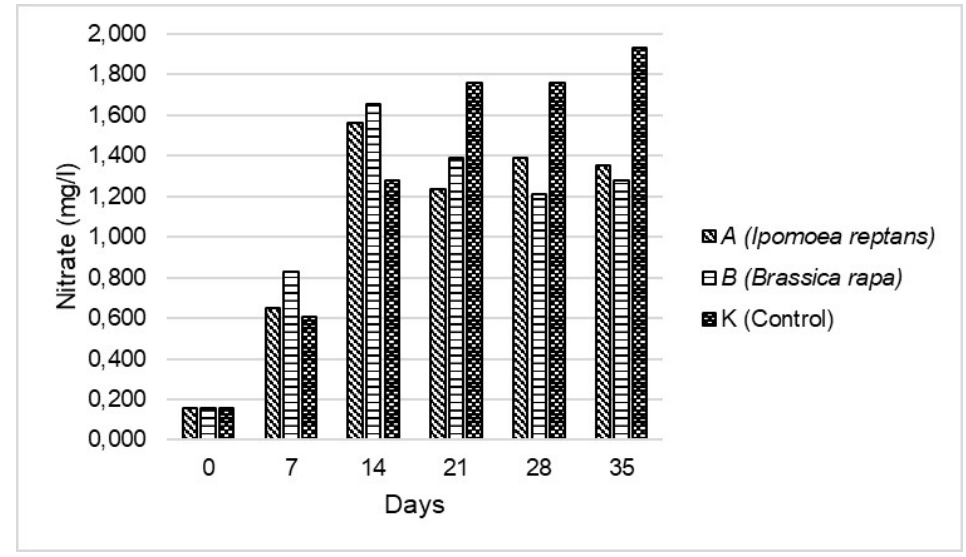

Figure 3 - Nitrate concentration

Figure 4 shows the gill tissue of tilapia between treatments. Damage that occurs in the form of hyperplasia, fusion and hemorrhage. Figure $4-a, b, c$ shows the gill tissue there is swelling or attachment of the lamellae called hyperplasia which is an advanced stage of edema damage. Tilapia (Oreochromissp.) gills experience edema which continues to cause cells to hyperplasia and the longer it will experience necrosis (cell shrinkage) (Rifqiyatiet al., 2017). Hyperplasia can be recognized from swollen tissue and the shape of the cell structure in it is not clear but still has epithelial tissue (Wikiandy et al., 2013; Juanda and Edo, 2018). Hyperplasia makes the gill lamellae (a soft structure, fresh red in color, has a wide surface and is the main place for the respiration process) to look larger than normal and the gills are no longer clearly visible the difference between the primary lamellae and the secondary lamellae (Nirmala etal., 2012; Jamin and Erlangga, 2016). 

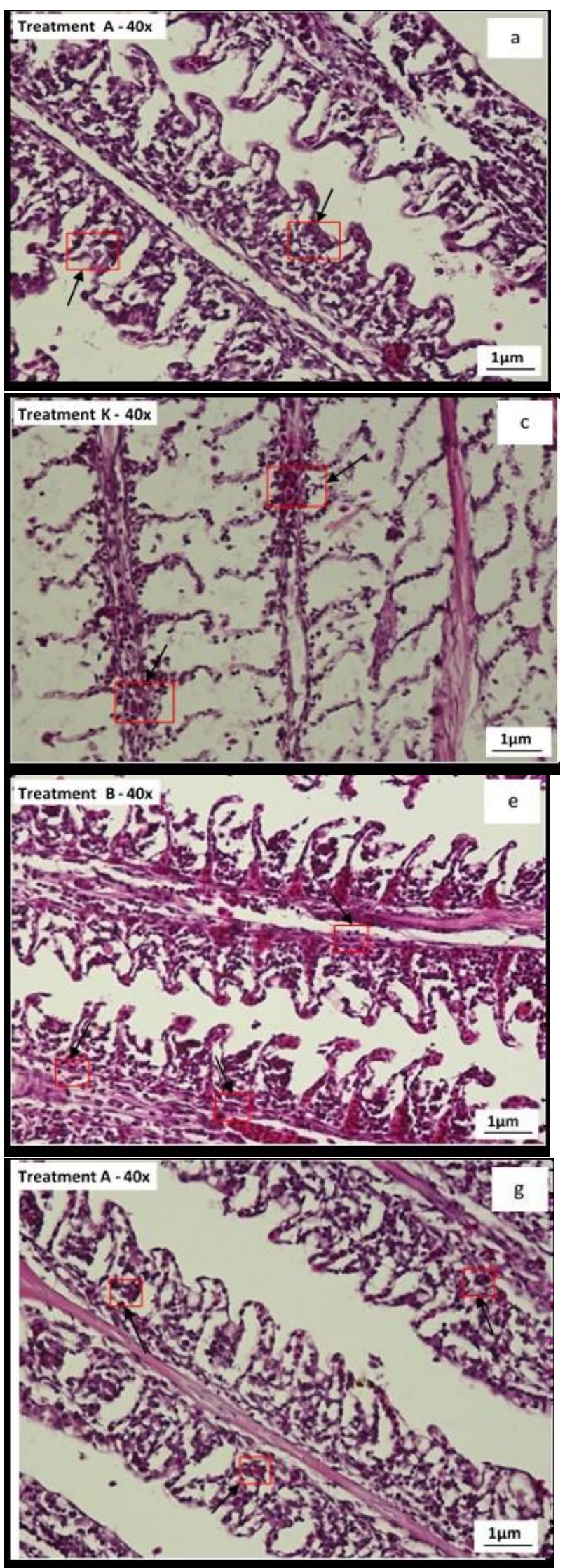
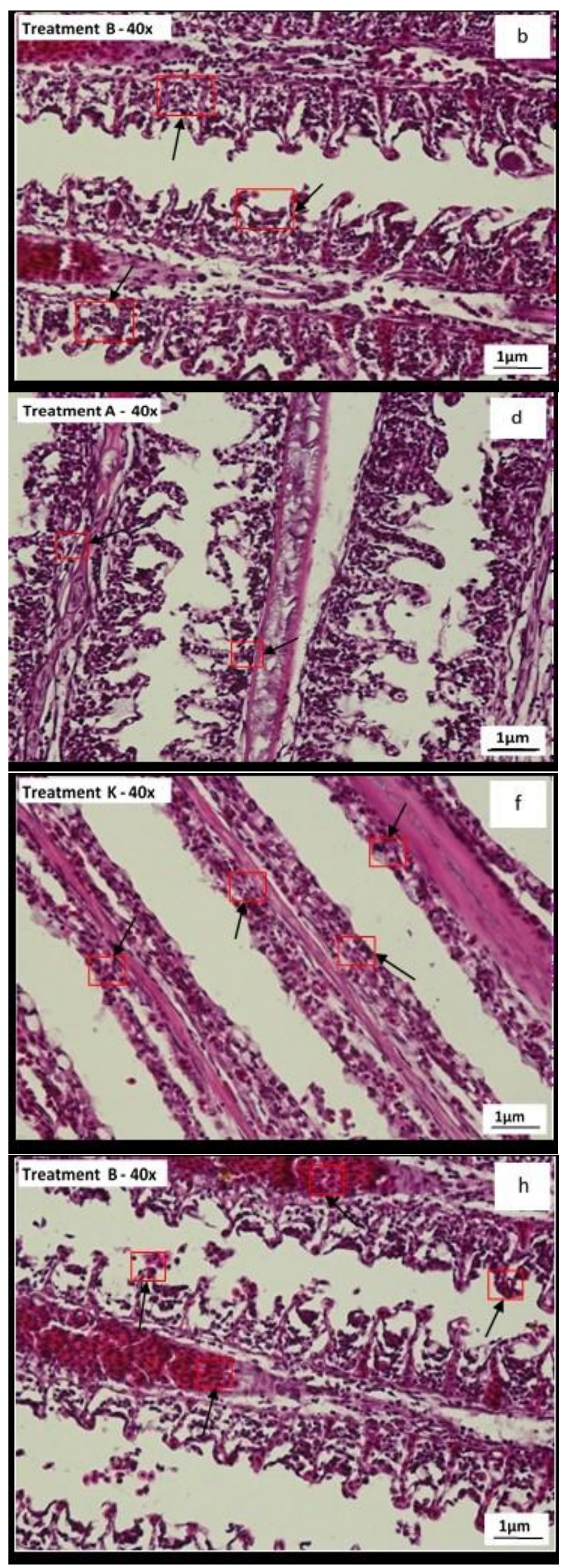


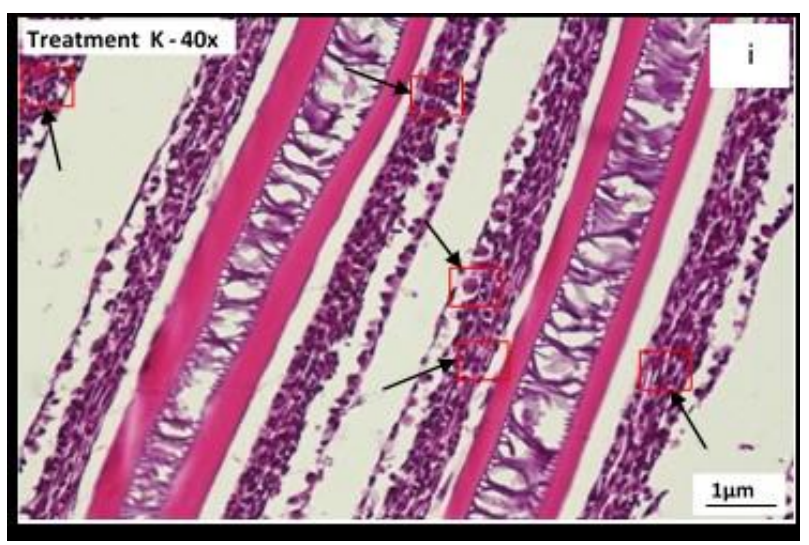

Figure $4-a)$ Treatment A (Hyperplasia), b) Treatment B (Hyperplasia), c) Treatment K (Hyperplasia),

d) Treatment A (Fusion), e) Treatment B (Fusion), f) Treatment K (Fusion), g) Treatment A

(Hemorrhage), h) Treatment B (Hemorrhage), i) Treatment K (Hemorrhage).

Figure $4-d$, e, f shows that the fusion of lamellae occurs due to a continuous increase in hyperplasia and causes the secondary lamellae to fill with new cells which then triggers attachment on both sides of the lamellae (Saputra et al., 2013; Sipahutar et al., 2013; Sipahutaret al., 2013). Fusion of gill tissue is classified as a severe level of damage; it can be seen from the fusion of two or more tissues due to epithelial tissue damage and is also characterized by the loss or absence of secondary lamellae on the gills (Mutiara et al., 2013; Juanda and Edo, 2018). Fusion of secondary lamellae can lead to telangiectasia and result in fish death due to lack of oxygen and changes in ion osmoregulation of the fish body (Utamiet al., 2017).

Figure 4 - g, h, i shows hemorrhage (bleeding) that can be recognized by the presence of blood spots with small or large spots, this happens when the congestion is very severe, the blood vessels will burst and the blood is in the wrong place (bleeding) (Jamin and Erlangga, 2016; Juanda and Edo, 2018). Hemorrhage causes disruption of blood supply to epithelial cells which is characterized by bleeding, namely the discovery of a red spot that spreads (Juanda and Edo, 2018).

Table 1- Histopathological scoring on tilapia gills

\begin{tabular}{|c|c|c|c|c|c|c|}
\hline \multirow{2}{*}{ Pathological Abnormalities } & \multirow{2}{*}{ Treatment } & \multicolumn{3}{|c|}{ Repetition } & \multirow{2}{*}{ Total } & \multirow{2}{*}{ Average } \\
\hline & & 1 & 2 & 3 & & \\
\hline \multirow{3}{*}{ Hyperplasia } & $A$ & 0,40 & 0,80 & 1,00 & 2,20 & $0,73 \pm 0,31$ \\
\hline & $\mathrm{B}$ & 1,00 & 1,20 & 1,20 & 3,40 & $1,13 \pm 0,12$ \\
\hline & $\mathrm{K}$ & 1,60 & 1,60 & 1,80 & 5,00 & $1,67 \pm 0,12$ \\
\hline \multirow{3}{*}{ Fusion } & $A$ & 0,00 & 0,00 & 0,20 & 0,20 & $0,07 \pm 0,12$ \\
\hline & $\mathrm{B}$ & 0,00 & 0,40 & 0,00 & 0,40 & $0,13 \pm 0,23$ \\
\hline & $\mathrm{K}$ & 3,00 & 3,00 & 3,20 & 9,20 & $3,07 \pm 0,12$ \\
\hline \multirow{3}{*}{ Hemorrhage } & $A$ & 1,00 & 1,60 & 1,40 & 4,00 & $1,33 \pm 0,31$ \\
\hline & B & 2,00 & 2,20 & 2,00 & 6,20 & $2,07 \pm 0,12$ \\
\hline & $\mathrm{K}$ & 3,00 & 2,80 & 2,60 & 8,40 & $2,80 \pm 0,20$ \\
\hline
\end{tabular}

Based on Table 1, the scores for each treatment were obtained with damage in the form of hyperplasia, fusion and hemorrhage. The score for gill damage was in the form of the smallest hyperplasia in treatment $A$ with an average value of 0.73 and the smallest damage in treatment $\mathrm{K}$ with an average value of 1.67. The score for gill damage in the form of the smallest fusion in treatment $A$ with an average value of 0.07 and the smallest damage in treatment $\mathrm{K}$ with an average value of 3.07. The score for gill damage was in the form of the smallest hemorrhage in treatment $A$ with an average value of 1.33 and the smallest damage in treatment $\mathrm{K}$ with an average value of 2.80. Overall, it is known that of the three defects, treatment $A$ has the smallest scoring value and treatment $K$ has the largest scoring value. This is thought to be closely related to the results of the ammonia concentration during the study because ammonia is toxic to fish. Ammonia compounds are able to penetrate the gill 
membrane, causing cell irritation. Increased levels of ammonia in the environment can interfere with the excretion of ammonia or cause the absorption of ammonia from the environment. This results in the accumulation of ammonia in organs in the body such as the gills (Randall and Tsui, 2002). This statement is in accordance with the results in this study, that the gill tissue of tilapia in treatment $\mathrm{K}$ with the highest ammonia concentration had the highest damage score when compared to treatment $A$ and treatment $B$.

\section{CONCLUSION}

The use of water spinach in an aquaponic system resulted in lower levels of tilapia gill damage and lower concentrations of nitrogenous waste (ammonia and nitrite).

\section{REFERENCES}

1. Andayani, S., H. Suprastyani, G. D. A. Gumalaand U. Oktafa. 2017. Pengaruhpemberian bakteri Lactobacillus plantarumterhada phistopatologi dan hematologi ikan patinjambal (Pangasius djambal) yang diinfeksibakteri Edwarsiellatarda. Journal of Fisheries and Marine Science. 1(4): 31-38.

2. Andriani, Y., Zahidah, Y. Dhahiyat, H. Hamdani and R. Dewi. 2019. Performance of lettuce and water spinach in koi fish-based aquaponics system. Asian Journal of Fisheries and Aquatic Research. 3(4): 1-7.

3. Berlianti, N. A., C. S. Widodo and U. P. Juswono. 2014. Study on the effect of pollutant waste on the content of free radicals in the gill organs of tilapia (Oreochromis niloticus). Natural B. 2(4): 355-359.

4. Camargo, J. A., A. Alonso and A. Salamanca. 2005. Nitrate toxicity to aquatic animals: a review with new data for freshwater invertebrates. Chemosphere. 58:1255-1267.

5. Carvalho, T. L. A. B., A. A. Nascimento, C. F. S. Gonçalves, M. A. J. Santos and A. Sales. 2020. Assessing the histological changes in fish gills as environmental bioindicators in Paraty and Sepetiba bays in Rio de Janeiro, Brazil. Latin American Journal of Aquatic Research. 48(4): 590-601.

6. Cifuentes-Torres, L., G. Correa-Reyes and L. G. Mendoza-Espinosa. 2021. Can reclaimed water be used for sustainable food production in aquaponics?. Frontiers in Plant Science. 12: 1-10.

7. Colt, J. 2006. Water quality requirements for reuse systems. Aquacultural Engineering. 34: 143-156.

8. Deswati, N. Febriani, H. Pardi, Y. Yusuf and H. Suyani. 2018. Applications of aquaponics on pakcoy (Brassica rapa $L$ ) and nila fish (Oreochromis niloticus) to the concentration of ammonia, nitrite and nitrate. Oriental Journal of Chemistry. 34(5): 2447-2455.

9. Farhangi, M., H. G. Kananiand M. Kashani. 2014. Prevention of acute ammonia toxicity in Beluga, Huso Huso, using natural zeolite. Caspian J. Env. Sci. 12(2): 167-276.

10. Gumelar, W. R., I. Nurruhwati, SunartoandZahidah. 2017. Pengaruh Penggunaan Tigavarietas Tanaman pada sistem akuaponik terhadap konsentrasi total amonia nitrogen media pemeliharaan ikan koi. JurnalPerikanan dan Kelautan. 8(2): 36-42.

11. Hartami, P., N. SyahputraandErlangga. 2015. Teknologi Akuaponik Dengan Tanaman yang berbedaterhadap performa pertumbuhan ikan nila (Oreochromis niloticus). Jurnal Perikanan Tropis. 2(1): 72-90.

12. JaminandErlangga. 2016. Effect of organophosphate insecticides on gift tilapia (Oreochromis niloticus, Bleeker) seeds: histological analysis of liver and gills. Acta Aquatica. 3(2):46-53.

13. Juanda, S. J. and S. I. Edo. 2018. Histopatologiinsang, hati dan usus ikan lele (Clariasgariepinus) di kotaKupang, Nusa Tenggara Timur. SaintekPerikanan. 14(1): 2329.

14. Kaliba, A. R., K. O. Osewe, E. M. Senkondo, B. V. Mnembukaand K. K. Quagrainie. 2006. Economic analysis of niletilapia (Oreochromis niloticus) production in Tanzania. Journal of the World Aquaculture Society. 37(4): 464-473. 
15. Kawasaki, N., M. R. M. Kushairi, N. Nagao, F. Yusoff, A. Imai and A. Kohzu. 2016. Release of nitrogen and phosphorus from aquaculture farms to Selangor River, Malaysia. International Journal of Environmental Science and Development. 7(2): 113-116.

16. Mahariawan, I., M., D., W. E. Kusuma, A.Yuniarti and A. M.Hariati. 2021a. Application of wheat flour (Triticum aestivum) on spore density and sporulation efficiency of Bacillus megaterium isolated from Litopenaeus Vannamei Gastrointestinal tract. Biodiversitas. 22(9):3709-3715.

17. Mahariawan, I., M., D., W. E. Kusuma, A.Yuniarti and A. M.Hariati. 2021b. The effect of starting shocking time on carbon, nitrogen,and organic matter absorption of Bacillus megaterium BM1in vegetative and sporulation phases. IOP Conf. Ser.: Earth Environ. Sci. 750: 1-7.

18. Martin, J. D., B. G. Werner and J. H. Hotchkiss. 2003. Effects of carbon dioxide on bacterial growth parameters in milk as measured by conductivity. Journal of Dairy Science. 86(6): 1932-1940.

19. Mayunar. 1990. Pengendaliansenyawa nitrogen pada budidaya ikan dengansistemresirkulasi. Oseana. 15(1): 43-55.

20. Mutiara, A. A., I. Rustikawatiand T. Herawati. 2013. Akumulasi timbal (Pb) dan kadmium (Cd) sertakerusakan pada insang, hati dan daging ikan patin (Pangasius sp.) di wadukSaguling. JurnalPerikanan dan Kelautan. 4(4): 1-10.

21. Nirmala, K., Y. Hadiroseyaniand R. P. Widiasto. 2012. Penambahan garam dalam air media yang berisi zeolite dan arangaktif pada transportasisistemtertutupbenih ikan gurami Osphronemusgouramy Lac. Jurnal Akuakultur Indonesia. 11(2): 190-201.

22. Putri, A. O., O. Y. T. Pamula, Y. Fakhriah, Prayogo, Sudarno, A. Manan, L. A. Sari and N. N. Dewi. 2019. The comparison of water spinach (Ipomoea aquatica) density using aquaponic system to decrease the concentration of ammonia $\left(\mathrm{NH}_{3}\right)$, nitrite $\left(\mathrm{NO}_{2}\right)$, nitrate $\left(\mathrm{NO}_{3}\right)$ and its effect on feed conversion ratio and feed efficiency to increase the survival rate and specific growth rate of african catfish (Clarias sp.) in intensive aquaculture. Journal of Aquaculture and Fish Health. 8(2): 113-122.

23. Rahmadhani, L. E., L. I. Widuriand P. Dewanti. 2020. Kualitasmutusayurkasepak (kangkung, selada, dan pakcoy) dengansistembudidayaakuaponik dan hidroponik. JurnalAgroteknologi. 14(1): 33-43.

24. Randall, D.J. and T. K. N. Tsui. 2002. Ammonia toxicity in fish. Marine Pollution Bulletin. 45: 17-23.

25. Rifaiyati, N., M. J. Luthfiand A. N. Miftah. 2017. Gambaran histologiinsang ikan mas koki (Carassius auratus) yang terinfeksiektoparasit Argulus sp. JurnalBionature. 18(1): 1-7.

26. Saputra, H. M., N. Marusin dan P. Santoso. 2013. Struktur histologisinsang dan kadarhemoglobin ikan asang (Osteochilushasseltii C.V.) di danau Singkarak dan Maninjau, Sumatera Barat. Jurnal Biologi Universitas Andalas. 2(2): 138-144.

27. Setyawan, N., N. Kariadaand E. Peniati. 2013. Mikroanatomi Insang ikan sebagai indikator pencemaran logam berat di perairan Kaligarang Semarang. Unnes Journal of Life Science. 2(1): 50-56.

28. Sipahutar, L. W., D. Aliza, WinaruddinandNazaruddin. 2013. Gambaran histopatologi insang ikan nila (Oreochromis niloticus) yang dipelihara dalam temperatur air di atas normal. JurnalMedikaVeterinaria. 7(1): 19-21.

29. Somerville, C., M. Cohen, E. Pantanella, A. Stankusand A. Lovatelli. 2014. Small-scale aquaponics food production: integrated fish and plant farming. Food and Agriculture Organization of the United Nations (FAO). Rome. 262 p.

30. Sriyoto, ReswitaandHardianto. 2015. Analisis distribusi pendapatan pada usaha ikan nila di kecamatanseginim, kabupaten Bengkulu Selatan. AGRISEP. 15(2): 159-166.

31. Su, M. H., E. Azwar, Y. F. Yang, C. Sonne, P. N. Y Yek, R. K. Liew, C. K. Cheng, P. L. Show and S. S. Lam. 2020. Simultaneous removal of toxic ammonia and lettuce cultivation in aquaponic system using microwave pyrolysis biochar. Journal of Hazardous Materials. 396: 1-10. 
32. Sukoco, F. A., B. S. Rahardjaand A. Manan. 2016. The effect of giving different probiotics in aquaponic systems on fcr (feed convertion ratio) dan biomassa ikan lele (Clarias sp.). Journal of Aquaculture and Fish Health. 6(1): 24-31.

33. Sweidan, A. H., N. E. Bendary, O. M. Hegazy, A. E. Hassanienand V. Snaself. 2015. Water pollution detection system based on fish gills as a biomarker. Procedia Computer Science. 65: 601-611.

34. Tuhuteru, S. 2018. Efektivitas hara makro dan mikro terhadap pertumbuhan tanaman jagung (Zea mays L.). Jurnal Agroekotek. 10(1): 65-73.

35. Utami, I. A. Y. S., A. A. A. Ciptojoyoand N. N. Wiadnyana. 2017. Histopatologiinsang ikan patinsiam (Pangasius hypophthalmus) yang terinfestasi trematoda monogenea. Media Akuakultur. 12(1): 35-43.

36. Wahyuningsih, S. and A. M. Gitarama. 2020. Amonia pada sistembudidaya ikan. Syntax Literate: Jurnalllmiah Indonesia. 5(2): 112-125.

37. Wantasen, W. 2015. Residupupuk nitrogen di lingkungan perairan hulu daerah aliran sungai tondano provinsi Sulawesi Utara. Jurnal Bumi Lestari. 15(2): 176-183.

38. Widanarni, S. G. PranotoandSukenda. 2010. Seleksi Bakteri Nitrifikasi dan denitrifikasi serta aplikasinya pada media budidaya udang vaname (Litopenaeusvannamei). Jurnal Akuakultur Indonesia. 9(2): 184-195.

39. Wikiandy, N., Rosidahand T. Herawati. 2013. The impact of textile industry waste pollution on the damage to the organ structures of fish that live in river basin areas (DAS) Citarumbagianhulu. Jurnal Perikanan dan Kelautan. 4(3): 215-225.

40. Wongkiew, S., Z. Hu, K. Chandran, J. W. Lee and S. K. Khanala. 2017. Nitrogen transformations in aquaponic systems: a review. Aquacultural Engineering. 76: 9-19. 